\title{
Pemanfaatan RinfoForm Sebagai Media Pengumpulan Data Kinerja Dosen
}

\author{
Indri Handayani $^{1}$ \\ Ignatius Joko Dewanto ${ }^{2}$ \\ Dina Andriani ${ }^{3}$
}

\begin{abstract}
Dosen STMIK Raharja ${ }^{\mathbf{1}, 2}$, Mahasiswa STMIK Raharja ${ }^{3}$
E-mail: indri@raharja.info ${ }^{1}$,jokodewanto@raharja.info ${ }^{2}$,dina.andriani@raharja.info ${ }^{3}$
\end{abstract}

\begin{abstract}
ABSTRAK
Teknologi informasi yang berkembang begitu pesat sehingga setiap Perguruan Tinggi senantiasa bersaing dalam kegiatan penelitian yang dilakukan oleh peneliti dan dosen. Salah satunya Perguruan Tinggi Raharja yang bergerak dibidang komputer. Perguruan Tinggi Raharja yang memiliki banyak inovasi untuk menciptakan media pengumpulan data kinerja dosen yang tidak konvensional. Untuk itu dibuatlah sebuah media informasi yang dijadikan sebagai media dalam pengumpulan data dosen yang ada di Perguruan Ting gi Raharja. Kinerja Penelitian dan Kinerja Pengabdian kepada Masyarakat yang merupakan sebagai bagian dari Tri Dharma Perguruan Tinggi Raharja yaitu pusat bagi Perguruan Tinggi dalam pengembangan Ilmu Pengetahuan, Teknologi, dan IPTEKS. Dalam implementasinya saat ini masih kurang efektif yaitu dalam pengumpulan data kinerja dosen. Hal ini masih terlihat pada saat ingin menginput data dosen, dosen harus datang ke ruangan Rahaja Enrichment Centre (REC). Maka dari itu pastinya saat ini mayoritas pasti memiliki email. Dikarenakan email merupakan salah satu media yang paling aman, dengan email mudah sekali dalam bertukar file atau dalam hal yang lainnya. Dan pastinya akan memanfaatkan fasilitas yang ada pada email. salah satunya yang terdapat pada gmail adalah Google Form. Google Form ini memiliki fungsi yaitu untuk membuat formulir pendaftaran dan untuk membuat daftar - daftar lain yang kemudian dengan cara meminta kepada seseorang untuk mengisi formulir yang telah dibuat sesuai dengan ketentuan yang ada. Akan tetapi pada Perguruan Tinggi Raharja ini lebih dikenal sebagai Rinfo Form. Dengan melalui Rinfo Form ini diketahui dapat menutupi kekurangan yang berpengaruh dalam pengumpulan data kinerja dosen tersebut. Dalam penelitian ini dilakukan dengan menggunakan metode pengumpulan data, diantaranya yaitu metode observasi dan metode studi pustaka. Peneliti berharap dengan pemanfaatan Rinfo Form memberikan pengaruh baik dalam pengumpulan data kinerja dosen di Perguruan Tinggi Raharja.
\end{abstract}

Kata kunci: Teknologi informasi, Data, RinfoForms

\footnotetext{
ABSTRACT

Information technology is growing very rapidly so that every university is always competing in research activities undertaken by researchers and lecturers. One of them is Perguruan Tinggi Raharja which is engaged in computer. Perguruan Tinggi Raharja has many

14 | Indri, Ignatius, Dina - Pemanfaatan Rinfo Form Sebagai Media...
} 
innovations to create unconventional lecturer data performance data collection. For that made a media information that serve as a medium in the data collection of lecturers in Perguruan Tinggi Raharja. Performance Research and Performance Devotion to the Society which is a part of Tri Dharma Perguruan Ting gi Raharja is the center for Universities in the development of Science, Technology, and IPTEKS. In the current implementation is still less effective in the collection of lecturer performance data. It is still visible at the time to enter the data of lecturers, lecturers must come to the room Raharja Enrichment CentRE (REC). Therefore of course now majority must have mail. Because email is one of the most secure media, with very easy email in exchangefiles or in other things. And certainly will take advantage of existing facilities on mail. One of which is in gmail is Google Form. This Google Form has a function that is to create other lists later by asking someone to fill out form that has been created in accordance with the existing provisions. However, in Perguruan Ting gi Raharja is better known as Rinfo From. By through Rinfo Form is known to cover the inadequate deficiencies in the collection of lecturer performance data. In this research is done by using data collection method, such us observation method, and literature review. Researchers hope by utilizing Rinfo Form give good influence in data performance data at Perguruan Tinggi Raharja.

Keywords : Information technology, Data, RinfoForms

\section{PENDAHULUAN}

Dengan begitu pesatnya perkembangan teknologi informasi, dapat memudahkan setiap kalangan baik itu kalangan pendidik dan kalangan pebisnis memanfaatkan teknologi informasi sebagai media untuk mengakses sebuah informasi secara efesien dan efektif, salah satunya di bidang pendidikan. Mengingat di era globalisasi yang saat ini semua kegiatan dituntut untuk serba cepat agar mampu bersaing dengan Perguruan Tinggi lainnya. Sehingga hampir setiap perguruan tinggi senantiasa bersaing untuk meningkatkan kualitas dan kuantitas penelitian yang dilakukan oleh para peneliti dan dosen. Hal ini tentunya juga dipengaruhi oleh semakin berkembangnya kemajuan teknologi informasi.

Dengan kemajuan teknologi informasi ini banyak sekali Perguruan Tinggi memanfaatkan dengan sebaik mungkin dalam mendukung kegiatan pokok utama dalam setiap Perguruan Tinggi yaitu Tri Dharma Perguruan Tinggi. Pengajaran, penelitian dan pengabdian kepada masyarakat. Salah satunya Perguruan Tinggi Raharja. Sebagaimana yang diketahui, Penelitian dan Pengabdian Masyarakat ini merupakan unsur akademik kegiatan penelitian sebagian dari tugas pokok utama di perguruan tinggi yang dilakukan oleh para peneliti dan dosen guna untuk mengembangkan ilmu pengetahuan dan IPTEK.

Perguruan Tinggi Raharja merupakan salah satu Perguruan Tinggi yang bergerak di bidang IT (Information Technology). Perguruan Tinggi Raharja harus terus berinovasi untuk menciptakan media sistem informasi sesuai dengan arus berkembangnya teknologi informasi untuk kebutuhan di Perguruan Tinggi Raharja. 
Dimana teknologi informasi memiliki peran penting dalam kehidupan sehari-hari dan banyak manfaatnya yang dirasakan. Maka dari itu dalam proses pengumpulan data kinerja dosen juga harus mengalami perubahan yang signifikan ke arah yang lebih baik. Saat ini untuk proses pengumpulan data dosen di Perguruan Tinggi Raharja masih kurang efektif. Ketika ingin melakukan penginputan, dosen tersebut harus mengirimkan melalui email, pastinya terlebih dahulu data-data yang akan di input harus disiapkan. Namun, terkadang hal itu memicu terjadi kesalahan dalam menginput data, seperti yang sering terjadi pada Link URL (Uniform Resource Locator). Dari segi operator, sebagai salah satu yang bertugas untuk melakukan mengumpulkan, menyimpan, menginput, dan menyebarluaskan. Perlunya suatu inovasi baru yang dilakukan dalam menunjang proses pengumpulan data kinerja dosen yang kemudian data tersebut akan di input pada SIMLITABMAS. Kekurangan dari proses pengumpulan data kinerja dosen ini adalah kesulitannya ketika ingin melakukan penginputan data kinerja dosen pada SIMLITABMAS yang bertujuan untuk meningkatkan kualiatas, kuantitas penelitian, serta menerapkan inovasi IPTEKS di Perguruan Tinggi dikarenakan adanya data kinerja dosen yang belum terupdate dan perlunya harus mencari data - data kinerja dosen.

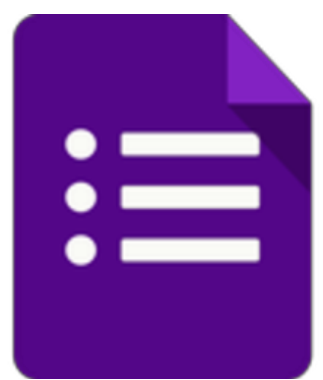

\section{Gambar 1. Logo Google Form Sumber : Rinfo Form}

Oleh karena itu, untuk mengantisipasi dalam mendukung proses pengumpulan data kinerja penelitian dan pengabdian kepada masyarakat agar lebih berjalan lebih optimal. Peneliti memanfaatkan RinfoForm. Rinfo Form/Google Form atau yang disebut google formulir adalah alat yang berguna untuk membantu merencanakan acara, mengirim survei, memberikan siswa atau orang lain kuis, atau mengumpulkan informasi yang mudah dengan cara efesien (Widuri : 2017). Dengan memanfaatkan RinfoForm dalam proses pengumpulan data kinerja dosen, maka pada saat melakukan penginputan data kinerja penelitian dan pengabdian kepada masyarakat dosen pada SIMLITABMAS dapat dilakukan secara optimal.

\section{PERMASALAHAN}

Dalam sebuah penelitian, pastinya diperlukan sebuah rumusan masalah, rumusan masalah yang menjadi faktor utama dalam sebuah penelitian yang menentukan 
jalannya dalam sebuah penelitian atau sebagai proses dari beberapa tahapan-tahapan untuk membuat sebuah karya ilmiah atau penelitian. Rumusan masalah yang berkaitan dengan sebuah kejadian atau peristiwa nyata, baik itu kedudukannya maupun kejadian atau peristiwa yang saling berkaitan antara satu dengan lainnya.

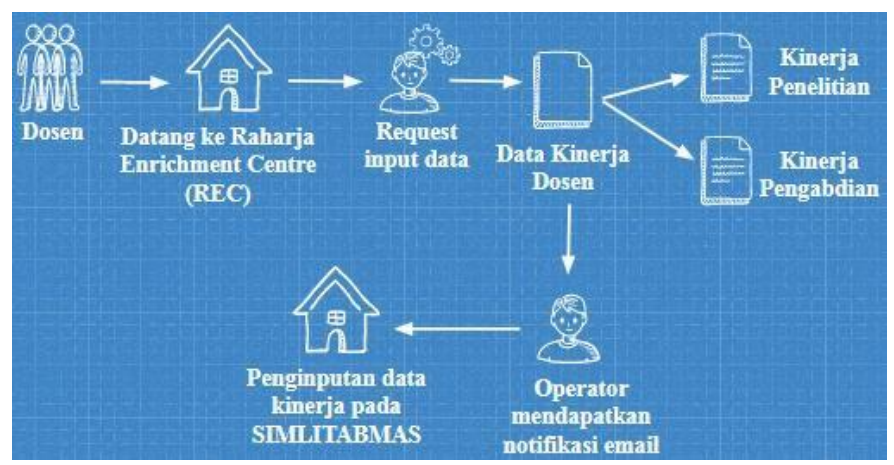

Gambar 2. Rumusan Masalah.

Berdasarkan gambar diatas, saat ini dalam pengumpulan data kinerja dosen masih terbilang kurang efektif. Ketika dosen ingin melakukan akses data, dosen tersebut harus mendatangi ruang Raharja Enrichment Centre (REC) untuk akses data yang kemudian dosen tersebut mengirimkan berkas data kinerja melalui email dan pastinya data-data yang akan diinput perlu disiapkan. Namun terkadang hal tersebut dapat memicu terjadi kesalahan melakukan input data kinerja dan rentang hilang.

Dari segi operator, permasalahan yang sering terjadi ketika ingin melakukan penginputan data kinerja dosen pada SIMLITABMAS, terkadang mengalami kesulitan dalam mendapatkan data-data dosen yang dibutuhkan dalam input data kinerja dosen yang sesuai panduan Ristekdikti. Jika data tersebut tidak lengkap maka data kinerja dosen tersebut tidak dapat untuk di submit dan kurangnya informasi bagi dosen perihal data-data kinerja yang akan akan diinput.

Dalam hal ini maka diperlukannya inovasi terbaru untuk mengantisipasi pengumpulan data kinerja dosen agar berjalan lebih optimal, dengan menggunakan salah satu fasilitas yang ada Google Drive yaitu Google Form/Rinfo Form. Dan memanfaatkan Rinfo form sebagai alat dalam melakukan pengumpulan data kinerja dosen sehingga data yang di dapat berjalan secara efektif.

\section{METODE PENELITIAN}

Dalam melakukan penelitian sudah tentunya menggunakan metode penelitian yang merupakan serangkaian tata cara yang dilakukan dalam melakukan suatu penelitian. 


\subsection{Metode Pengumpulan Data}

Sebagai awal dari proses penelitian yang dilakukan, Metode pengumpulan data merupakan tahap yang sangat penting dalam sebuah penelitian, data-data tersebut yang terkumpul merupakan bahan utama yang menjadi inti dari objek penelitian. Menurut Darmawan dan Fauzi (2013: 1), Data adalah fakta atau apa pun yang dapat digunakan sebagai input dalam menghasilkan informasi. Menurut Gorgon B. Davis dalam Hutahaean (2015: 9), Informasi adalah data yang telah diolah menjadi suatu bentuk yang penting bagi si penerima dan mempunyai nilai nyata atau dapat dirasakan dalam keputusan-keputusan yang sekarang atau keputusan-keputusan yang akan datang.

\section{1.1 Metode Observasi (Pengamatan)}

Metode observasi ini merupakan salah satu metode yang diterapkan guna proses untuk mengumpulkan data dalam penelitian ini. Pada tahap ini dilakukan untuk mengetahui lebih jelas permasalahan yang diambil dalam penelitian dengan cara melakukan pengamatan langsung terhadap kegiatan yang berlangsung kepada proses berjalannya sistem. Dalam proses pengumpulan data ini peneliti mendapat beberapa permasalahan yang dihadapi pada sistem yang berjalan saat ini. Berikut adalah gambaran permasalahan yang terjadi saat ini dengan menggunakan Activity Diagram :

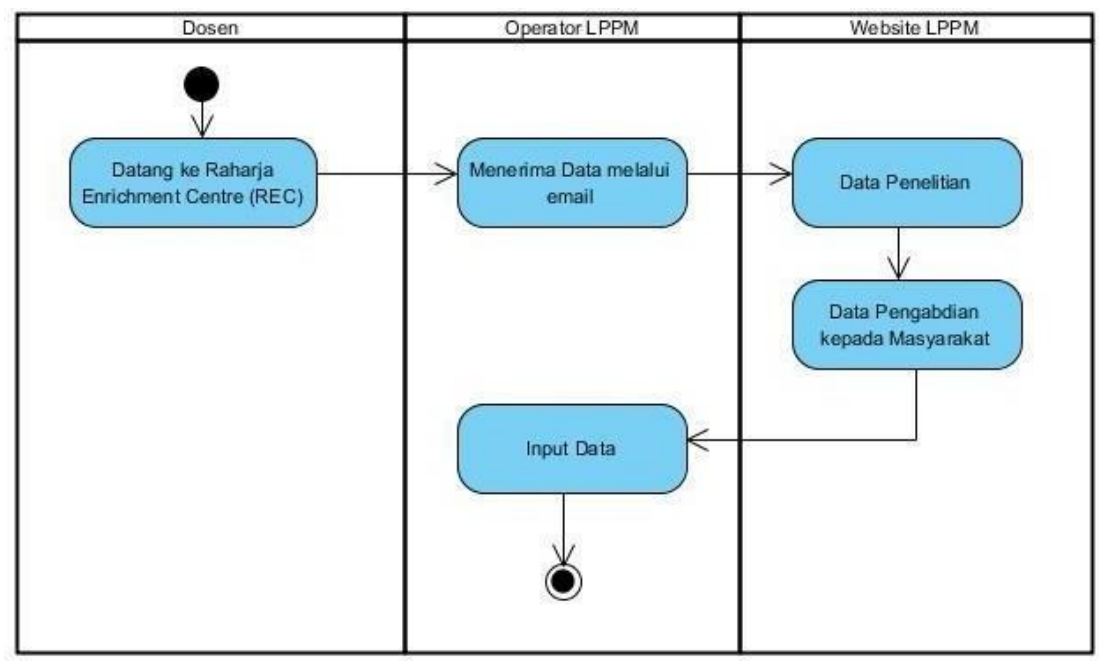

Gambar 3. Activity Diagram Permasalahan pada Sistem Yang Berjalan

Sesuai Permasalahan yang didapatkan melalui metode observasi ini, dapat disimpulkan bahwa prosedur dalam pengumpulan data yang saat ini masih belum efektif, dengan melalui email Rinfo. Dalam hal ini proses pengumpulan data-data dosen masih terbilang manual. 


\subsubsection{Metode Studi Pustaka}

Dalam upaya yang dilakukan untuk mendapatkan sebuah informasi yang relevan sesuai dengan topik atau masalah yang sedang diteliti. Metode ini berfungsi untuk mempelajari hasil yang di peroleh oleh setiap sumber dalam melakukan penelitian dan dapat memperdalam pengetahuan yang sudah diperoleh berkaitan dengan apa yang sedang diteliti sehingga dapat dipahami dengan baik. Berikut adalah beberapa penelitian yang dijadikan sebagai sumber pustaka.

1. Penelitian yang dilakukan oleh Untung Raharja, Indri Handayani, dan Baiq Aneji Pahad pada tahun 2016, dengan judul "Pemanfaatan RinfoFrom Sebagai Media Request Update Artikel pada iRAN". Penelitian ini membahas perihal pemanfaatan RinfoForm sebagai media Cloud Computing Rinfo yang dijadikan sebagai salah satu solusi agar dapat memberikan pengaruh terhadap pelayanan request yang ada di dalam iRAN. Rinfo Form yang dapat menjadi sebuah inovasi baru didalam pemberlakuan update di iRAN (iLearning Raharja Ask And News).

2. Penelitian yang dilakukan oleh Erlita Rasdiana, Fadil Nur Muhamad, dan Ridwan Kurniaji pada tahun 2016. dengan judul "Pemanfaatan RinfoForm Sebagai Media Pembuatan Kuisioner Dalam Pengumpulan Data Pada Perguruan Tinggi”. Penelitian ini membahas perihal pemanfaatan Google Form yang merupakan salah satu fasilitas yang terdapat email. Google Form yang digunakan sebagai aspek yang dapat membantu sekali dalam mempermudah pengumpulan data dengan melalui pembuatan kuisioner. Dimana pada Google Form ini digunakan oleh Tim OJRS + dalam pengumpulan data tingkat kepuasan mahasiswa dalam penggunaan sistem informasi OJRS+.

3. Penelitian ini dilakukan oleh Hamdan Husein Batubara pada tahun 2016, dengan judul "Penggunaan Google Form Sebagai Alat Penilaian Kinerja Dosen Di Prodi PGMI Uniska Muhammad Arsyad Al Banjari”. Penelitian ini membahas perihal penelitian penggunaan google form sebagai alat alternative penilaian kinerja dosen pada proses pembelajaran menunjukkan respon yang baik yaitu memberikan manfaat yang baik bagi mahasiswa dan dosen. Penelitian yang menggunakan metode deskriptif analistis dengan teknik pengumpulan data berupa angket dan studi dokumentasi.

4. Penilitian yang dilakukan oleh Bayu Febriadi dan Nurliana Nasution pada tahun 2017, dengan judul "Sosialisasi Dan Pelatihan Aplikasi Google Form Sebagai Kuisioner Online Untuk Meningkatkan Kualitas Pelayanan". Penelitian ini membahas perihal pengumpulan data permasalahan dengan memberi pelatihan google form dalam membuat kuisioner online untuk meningkatkan kualitas pelayanan yang terjadi pada kantor KKP kelas II Pekanbaru dengan belum adanya alat tolak ukur untuk menghitung kualitas pelayanan pada kantor 
kesehatan pelabuhan pekanbaru sehingga pimpinan susah dalam evaluasi dalam peningkatan layanan yang diberikan kepada masyarakat.

5. Penelitian yang dilakukan oleh Dwi Astuti, Kartono, dan Wardono pada tahun 2018, dengan judul "Analisis Kemampuan Literasi Matematika Model Pembelajaran JUCAMA berpendekatan PMRI dengan Google Form Sebagai Self Assessment". Penelitian ini membahas perihal mendeskripsikan keterlaksanaan kualitas pembelajaran JUCAMA berpendekatan PMRI dengan google form sebagai self assessment serta mendeskripsikan kemampuan PMRI kemampuan literasi matematika kelas XI IPA SMA Negeri 2 Semarang pada Pembelajaran JUCAMA berpendekatan PMRI dengan google form sebagai self assessment dapat dikatakan berkualitas.

\section{HASIL DAN PEMBAHASAN}

Pemanfaatan dengan menggunakan Rinfo Form dalam pengumpulan data dapat dijadikan sebagai salah satu solusi yang tepat untuk mengatasi masalah - masalah yang telah dijelaskan di atas. Rinfo Form adalah salah satu fasilitas yang terdapat pada Rinfo Drive yang diberikan oleh Rinfo. Sedangkan Rinfo adalah sebuah layanan email yang dibuat khusus oleh Perguruan Tinggi Raharja dan merupakan alat media komunikasi vital hanya bisa digunakan oleh para Pribadi Raharja.

Rinfo ini wajib dimiliki oleh Pribadi Raharja. Dikarenakan dalam semua aspek pembelajaran di Perguruan Tinggi Raharja secara keseluruhan menggunakan Rinfo sebagai media pendukung dalam kegiatan belajar mengajar. Dimana pada Rinfo ini memiliki platform yang sama dengan google. Dari segi pembedanya yaitu pada domain yang ada di belakangnya. Gmail memiliki domain gmail.com, sedangkan Rinfo memiliki domain raharja.info. Untuk Rinfo, jika mahasiswa tidak mempunyai Rinfo maka akan sulit dalam pembelajaran dan hal lainnya karena Perguruan Tinggi Raharja untuk akses dalam lingkup pembelajarannya menggunakan Rinfo.

Penelitian dan pengabdian kepada masyarakat merupakan sebagian dari Tri Dharma Perguruan Tinggi, yang demikian merupakan tugas utama di perguruan tinggi dalam melakukan kegiatan penelitian yang dilakukan oleh para peneliti dan dosen. Dan sebagai bagian dari salah satu pusat Perguruan Tinggi dalam pengembangan Ilmu Pengetahuan, Teknologi, dan IPTEKS. Maka dari itu penelitian dan pengabdian dosen ini mempunyai peran penting untuk meningkatkan kualitas dan kuantitas penelitian, serta dapat menerapkan inovasi IPTEKS untuk menciptakan produk penelitian.

Dapat dilihat, dengan Rinfo Form atau Google Form yang merupakan salah satu fasilitas yang ada pada Rinfo Drive. Dengan menggunakan Rinfo Form dapat mempermudah dalam pengumpulan data. Kemudian dengan melakukan pengisian melalui Rinfo Form ini akan terkumpul secara efektif dan akan tersimpan dengan baik. Berikut adalah gambaran alur yang akan terjadi. 


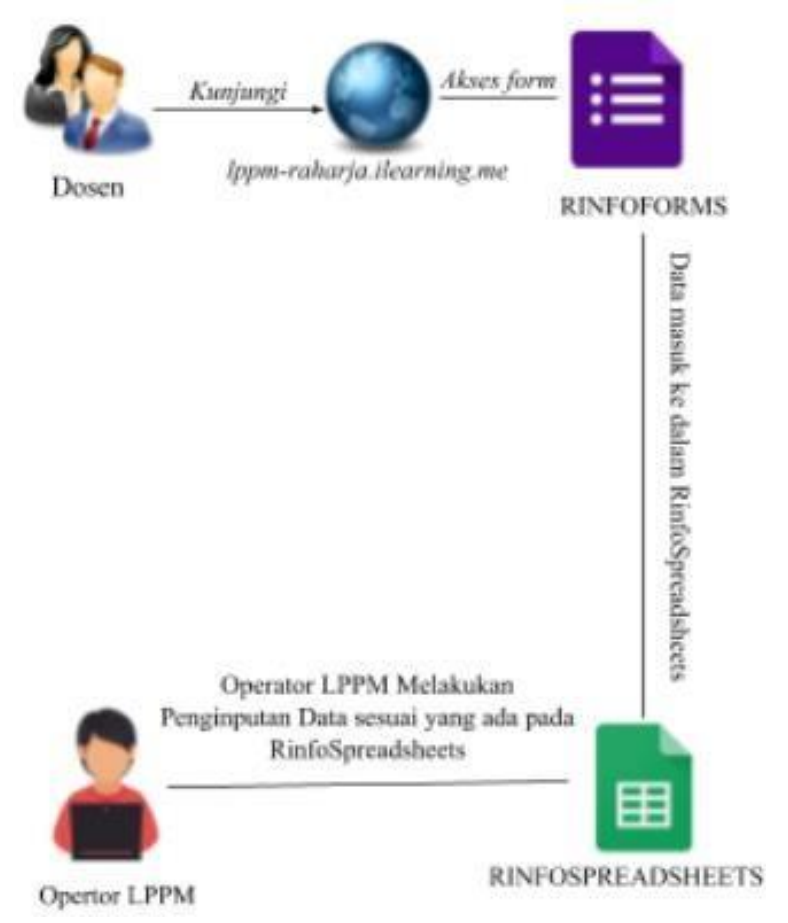

Gambar 4. Alur Sistem Yang Dïmplementasikan

Sesuai dengan gambar di atas, dapat dijelaskan bahwa memanfaatkan fasilitas yang ada pada Rinfo dalam pengumpulan data kinerja dosen dapat dilakukan dengan mudah melalui Rinfo Form. Dikarenakan data yang masuk tidak hanya pada email saja, melainkan secara otomatis data tersebut langsung ter-record dengan baik di dalam RinfoSpreadsheets. Dengan memanfaatkan internet yang ada, sehingga data - data yang sudah masuk tersebut aman dan tidak akan hilang.

Dengan menggunakan Rinfo Form ini manfaatnya dapat dirasakan karena Rinfo Form ini merupakan suatu proses awal kerangka dalam pengumpulan data yang sangat serbaguna. Khususnya pada zaman sekarang ini sudah banyak membutuhkan fasilitas fasilitas yang modern untuk memudahkan dalam akses sebuah informasi. Seperti di Bidang Pendidikan, yang sekarang ini banyak sekali setiap perguruan tinggi senantiasa bersaing dikarenakan perkembangan teknologi informasi sekarang ini berkembang begitu pesat.

Rinfo Form yang merupakan menjadi sebuah inovasi baru dalam pengumpulan data dosen di Perguruan Tinggi Raharja. Saat ini sudah diimplementasikan. Form dapat di akses melalui http//lppm-raharja.ilearning.me/ . Pada website ini terdapat dua menu page yang setiap menu nya terdapat Rinfo Form. diantaranya sebagai berikut. 


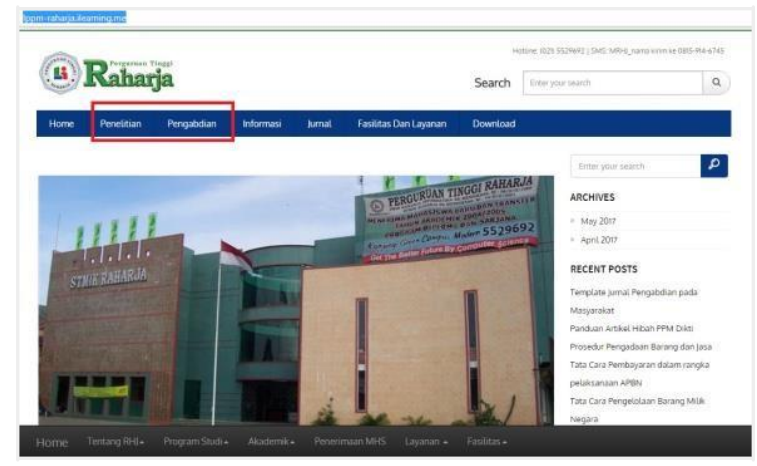

Gambar 5. 2 (dua) Menu Page Penelitian dan Pengabdian

Di dalam implementasi ini berikut diantaranya Rinfo Form yang terdapat pada setiap menu nya. Untuk menunjang dalam proses pengumpulan data kinerja dosen.

\section{Form Kinerja Penelitian Dosen}

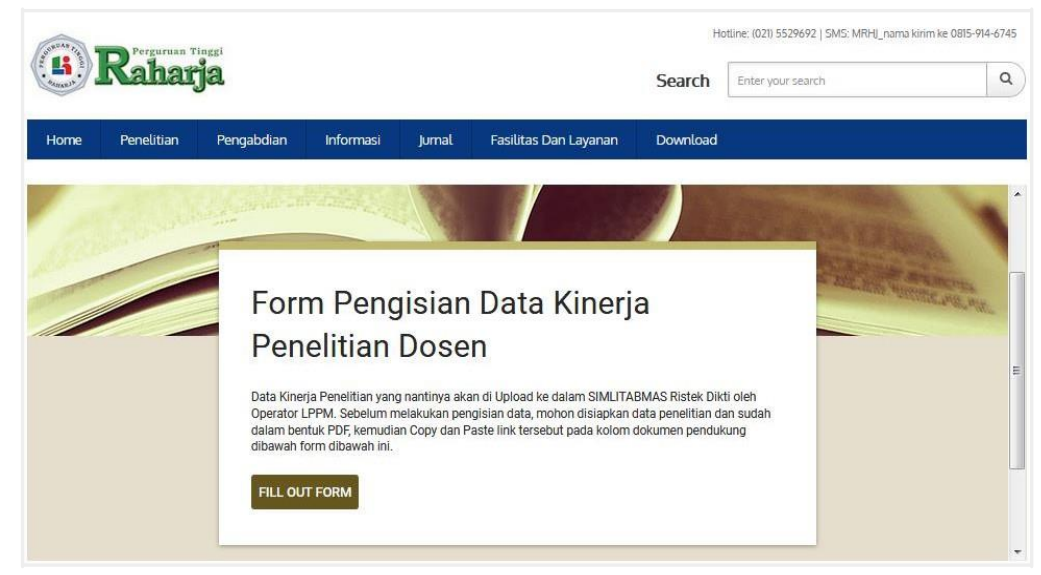

Gambar 6. Implementasi RinfoForm Kinerja Penelitian Dosen

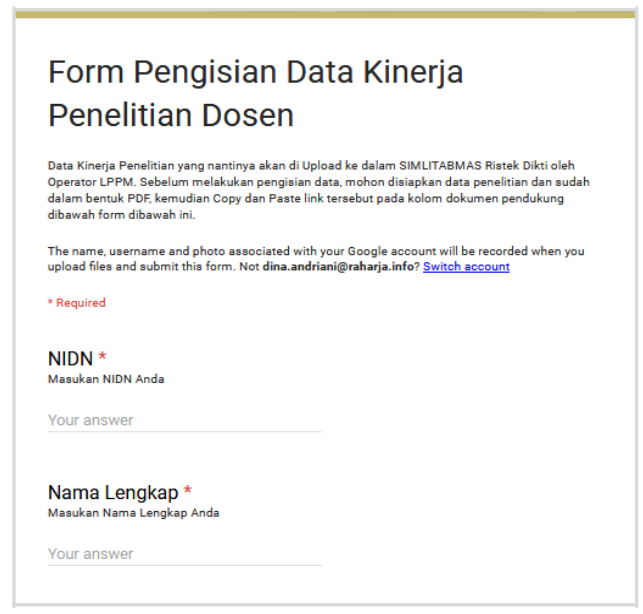

22 | Indri, Ignatius, Dina - Pemanfaatan Rinfo Form Sebagai Media... 


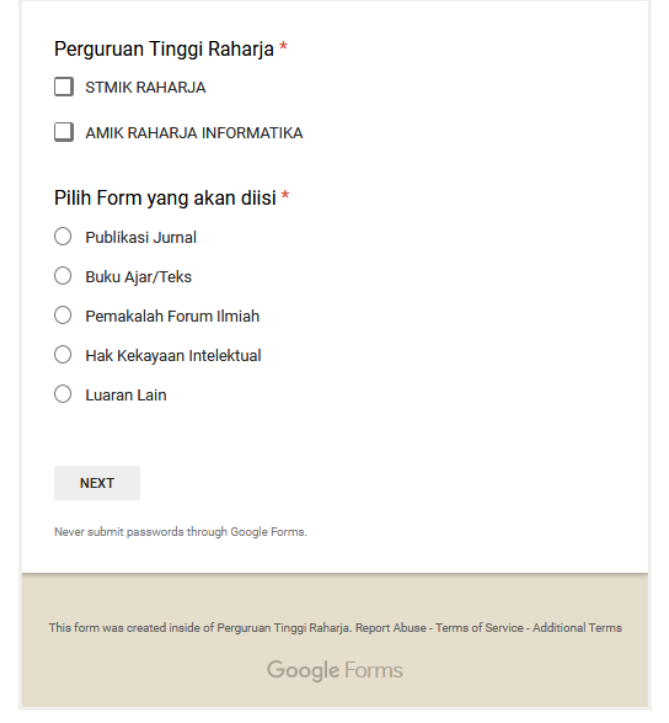

\section{Gambar 7. Form Pengisian Data Kinerja Penelitian Dosen}

Pada kinerja penelitian ini sebagai salah satu kegiatan yang wajib dilaksanakan di perguruan tinggi dengan harus selalu terjaga kualitas penyelenggaraannya, dimana luaran yang dihasilkan, dan kontribusinya terhadap kebutuhan masyarakat. Dalam kegiatan penelitian ini setiap perguruan tinggi diharapkan dapat mengelola kegiatan penelitian dengan memenuhi standar yang telah ditentukan. Penelitian ini merupakan salah satu Tri Dharma Perguruan tinggi yang diwajibkan yang terdapat pada Undang Undang Nomor 12 Tahun 2012. Penelitian untuk perguruan tinggi ini dengan tujuan dapat menjamin pengembangan penelitian unggulan spesifik dan dapat meningkatkan daya saing perguruan tinggi di bidang penelitian. Namun dalam pengisian data kinerja penelitian dosen melalui Rinfo Form ini bertujuan untuk mengumpulkan semua data dosen keseluruhan yang ada di Perguruan Tinggi Raharja. Dan dalam pengisian data kinerja penelitian ini hanya dapat di akses dengan menggunakan email Rinfo. Kemudian data yang sudah diisi melalui form kinerja penelitian akan masuk secara otomatis ke dalam Rinfo Spreadsheet, dan akan mendapatkan notifikasi bahwa data tersebut sudah berhasil. Pada kinerja penelitian ini untuk sebagai akreditasi institusi, pemetaan sumber daya penelitian.

\section{Form Kinerja Pengabdian Dosen}

23 | Indri, Ignatius, Dina - Pemanfaatan Rinfo Form Sebagai Media ... 


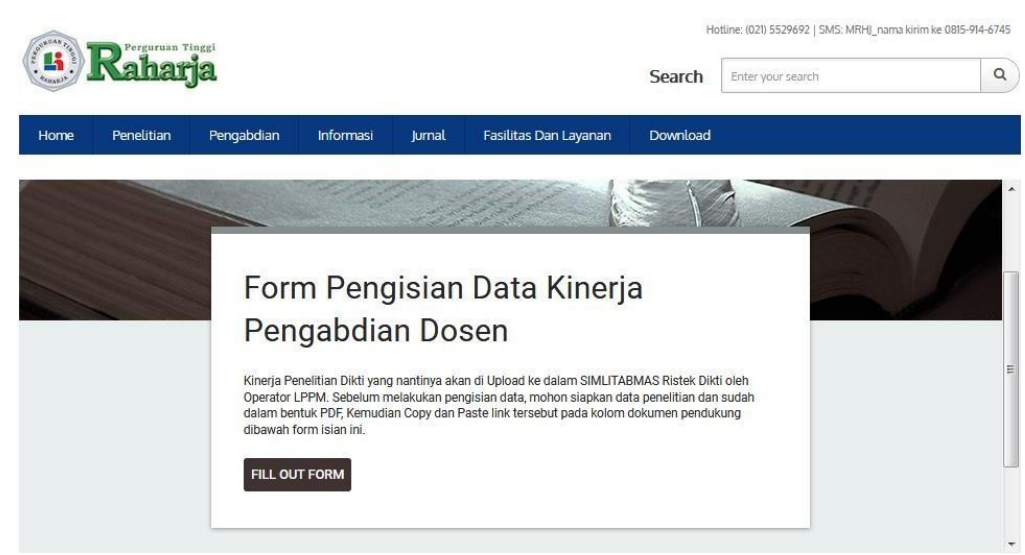

Gambar 8. Implementasi RinfoForm Kinerja Pengabdian Dosen

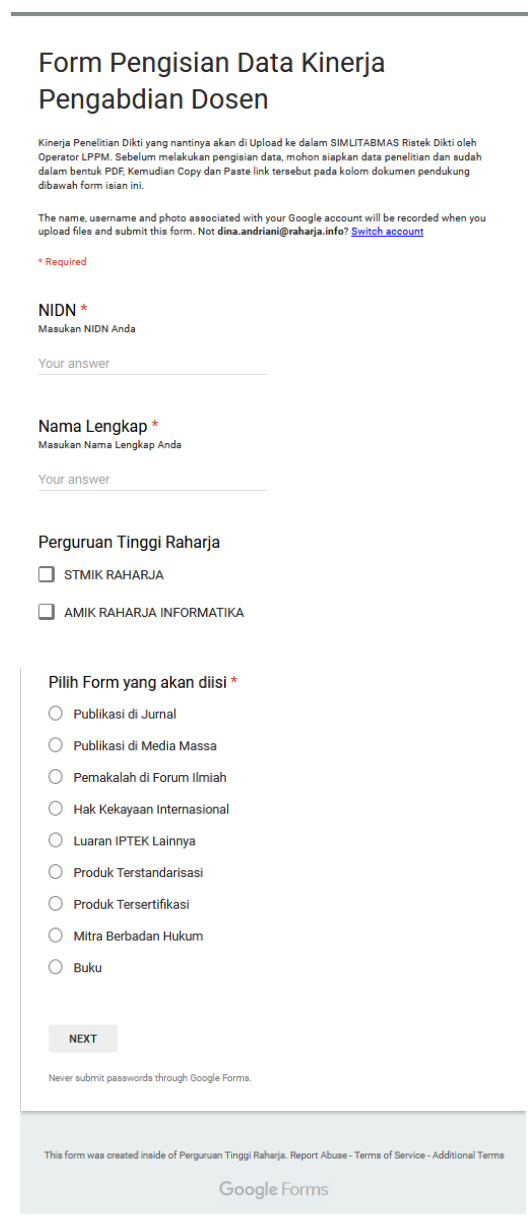

Gambar 9. Form Pengisian Data Kinerja Pengabdian Dosen

Pengabdian kepada masyarakat merupakan sebuah unsur pelaksana di lingkungan perguruan tinggi untuk menyelenggarakan kegiatan pengabdian kepada masyarakat serta ikut mengusahakan sumber daya yang diperlukan. Dalam pengabdian 24 | Indri, Ignatius, Dina - Pemanfaatan Rinfo Form Sebagai Media... 
kepada masyarakat ini dapat dilakukan melalui pusat penelitian, kelompok, dan perorangan. Pada kinerja pengabdian kepada masyarakat ini masih sama halnya dengan kinerja penelitian. Seperti yang kita ketahui saat ini bahwa penelitian dan pengabdian kepada masyarakat sudah menjadi satu yaitu dengan nama LPPM (Lembaga Penelitian dan Lembaga Pengabdian kepada Masyarakat). Dan LPPM merupakan Tri Dharma Perguruan Tinggi.

Tujuan dari adanya formulir di atas adalah untuk mengumpulkan data dosen keseluruhan yang ada di Perguruan Tinggi Raharja. Maka dari itu dalam pengumpulan data kinerja penelitian dan kinerja pengabdian kepada masyarakat di buatlah website LPPM Raharja. Dalam website LPPM Raharja ini terdapat form kinerja penelitian dosen dan form kinerja pengabdian dosen. Dan masih seperti yang sebelumnya dijelaskan pada form kinerja penilitian bahwa dalam melakukan pengisian data yang sudah diisi, akan secara otomatis masuk ke dalam Rinfo Spreadsheet kemudian akan mendapatkan notifikasi yang menandakan bahwa data anda sudah berhasil.

Namun, pada Rinfo Form yang ditampilkan pada gambar di atas. Dari semua ketentuan yang ada pada setiap Rinfo Form tersebut baik penelitian dan pengabdian. Untuk pengisian ketika sudah mengisi NIM dan Nama, selain itu pada formulir ini terdapat sedikit berbeda dengan formulir biasanya, dikarenakan dalam sebuah penelitian dan pengabdian yang dilakukan oleh dosen tidak hanya lingkup jurnal saja akan tetapi banyak hal lain yang di lakukan oleh dosen sebagai pengajaran, mengembangkan ilmu pengetahuan dan hal tersebut merupakan Tri Dharma Perguruan Tinggi. Sebagai Berikut:

a. Ruang Lingkup yang ada pada Kinerja Penelitian

1. Publikasi Jurnal

2. Buku Ajar atau Teks

3. Pemakalah Forum Ilmiah

4. Hak Kekayaan Intelektual

5. Luaran Lain

b. Ruang Lingkup yang ada pada Kinerja Pengabdian kepada Masyarakat

1. Publikasi di Jurnal

2. Publikasi di Media Massa

3. Pemakalah di Forum Ilmiah

4. Hak Kekayaan Intelektual

5. Luaran Iptek Lainnya

6. Produk Terstandarisasi

7. Produk Tersertifikasi

8. Mitra Badan Hukum

9. Buku 
Demikian dikarenakan Rinfo Form ini disatukan, maksud dari disatukan jadi untuk melakukan pengisian data melalui Rinfo Form baik Rinfo Form Penelitian maupun Rinfo Form Pengabdian pada bagian point pilihan tersebut memilih salah satu formulir yang akan di isi sesuai kebutuhan. Kemudian setelah sudah memilih pada saat klik Next. Maka akan tampil Rinfo Form yang yang telah dipilih. Dan pada Rinfo Form ini. Data dapat tersimpan secara otomatis ke dalam Rinfo SpreadSheets pada setiap kali dosen telah melakukan pengisian form. Dan ini merupakan fungsi dari Rinfo Form sebagai sebuah ekstensi dari Rinfo SpreadSheets. Dan dalam pemanfaatan ini sudah dilakukan oleh dosen guna untuk mengumpulkan data yang kemudian data tersebut akan di input oleh operator LPPM

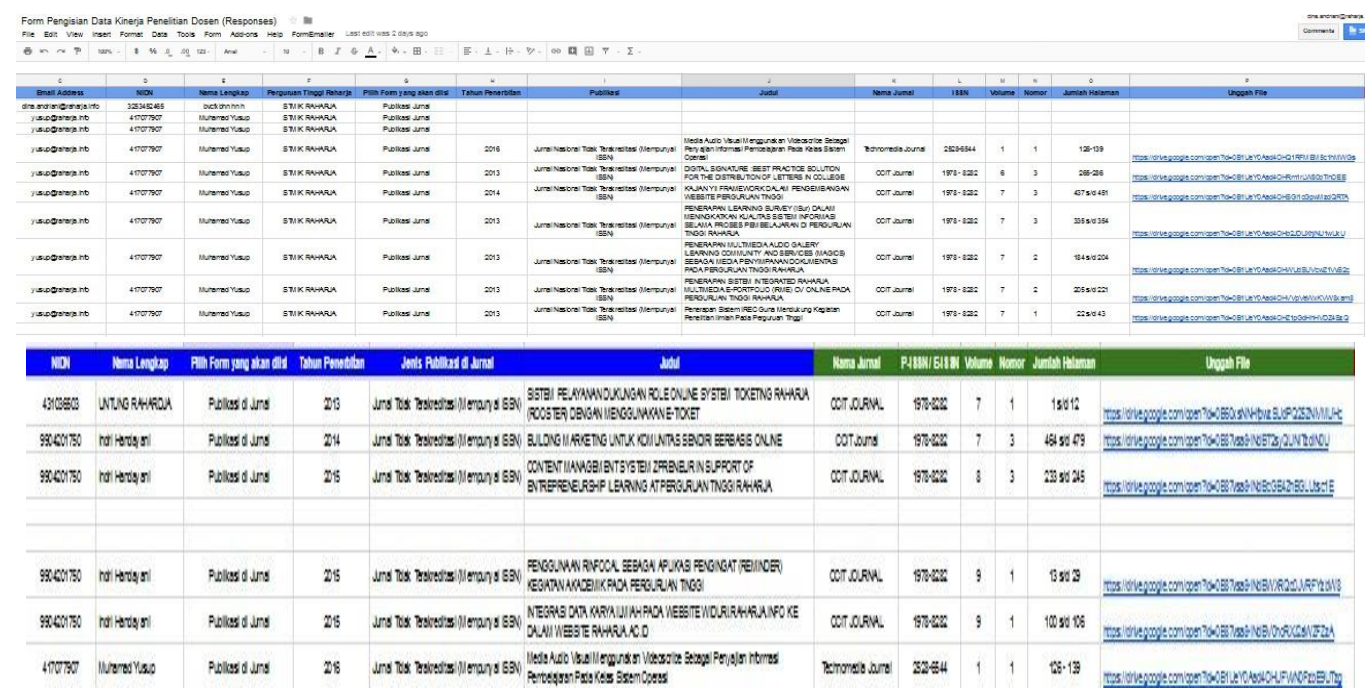

Gambar 10. Rinfo SpreadSheets data Kinerja Dosen

Dengan di terapkannya Rinfo Form ini tentunya memberikan beberapa hal positif dalam melakukan pengumpulan data kinerja dosen. Berikut terdapat beberapa kelebihan yang didapatkan dalam di terapkannya Rinfo Form.

1. Proses dalam pengumpulan data kinerja dosen dapat dilakukan secara efesien, karena semua data yang di isi dapat terkumpul secara otomatis. Dan operator LPPM dapat mengetahui informasinya dengan mendapatkan sebuah notifikasi berupa email.

2. Data yang masuk sudah ter-record dengan baik. Sehingga hal ini sangat mempermudah operator dalam melakukan penginputan data.

3. Lebih informatif lagi dengan penambahan pendataan penilaian kinerja penelitian dan pengabdian kepada masyarakat sesuai dengan panduan yang ada. 


\section{KESIMPULAN}

Demikian dapat disimpulkan bahwa dengan pemanfaatan Rinfo Form pada pengumpulan data kinerja dosen telah sesuai dengan kebutuhan - kebutuhan yang ingin ditampilkan. Maka dapat disimpulkan dengan adanya Rinfo Form ini dapat :

1. Rinfo Form dapat memberikan pelayanan yang baik dalam melakukan pengumpulan data Kinerja Penelitian Dosen dan kinerja Pengabdian Dosen.

2. Dengan adanya Rinfo Form dapat memberikan pemecahan masalah dan data secara real time, selain itu mendapatkan keuntungan tersendiri baik itu dosen maupun operator LPPM.

3. Dengan adanya Rinfo Form, ketika sedang adanya informasi yang terupdate dalam meningkatkan kualitas dan kuantitas dapat dilakukan secara efektif.

\section{SARAN}

Pada Perguruan Tinggi tentunya dalam penetapan kualitas selalu merupakan upaya sangat penting, karena pada kualitas kinerja sering menentukan keberlangsungan hidup suatu Perguruan Tinggi. Berdasarkan keseluruhan yang telah penulis uraikan dengan ini dapat menyimpulkan saran yaitu sebagai berikut :

1. Saat ini dalam penggunaan Rinfo Form sudah berjalan dengan baik. Namun perlunya pengembangan tampilan sehingga lebih menarik

2. Pada Rinfo Form yang di dalam formulirnya bercabang dengan beberapa pilihan. Kemudian data yang sudah di isi dan secara otomatis masuk ke dalam RinfoSpreadsheets tampilan nya dapat lebih simpel lagi.

3. Untuk membuat formulir pada Rinfo Form dengan adanya upload file dapat dengan mudah di embed secara langsung.

\section{DAFTAR PUSTAKA}

[1] Darmawan, Deni dan Kunkun Nur Fauzi. 2013. Sistem Informasi Manajemen. Bandung: PT Remaja Rosdakarya.

[2] Hutahaean, Jeperson 2015. Konsep Sistem Informasi. Yogyakarta: Deepublish.

[3] Raharja, U., Handayani, I., \& Pahad, B. A. (2016). PEMANFAATAN RINFOFORM, SEBAGAI MEDIA REQUEST UPDATE ARTIKEL PADA IRAN. CSRID (Computer Science Research and Its Development Journal), 8(3), 191-200.

[4] Rasdiana, E., Muhamad, F. N., \& Kurniaji, R. (2016). PEMANFAATAN RINFO FORM SEBAGAI MEDIA PEMBUATAN KUISIONER DALAM PROSES PENGUMPULAN DATA PADA PERGURUAN TINGGI. Technomedia Journal, 1(1), 78-94.

[5] Batubara, H. H. (2016). Penggunaan Google Form Sebagai Alat Penilaian Kinerja Dosen di Prodi PGMI Uniska Muhammad Arsyad Al Banjari. Al-Bidayah: Jurnal Pendidikan Dasar Islam, 8(1), 39-50.

27| Indri, Ignatius, Dina - Pemanfaatan Rinfo Form Sebagai Media... 
[6] Febriadi, B., \& Nasution, N. (2017). Sosialisasi Dan Pelatihan Aplikasi Google Form Sebagai Kuisioner Online Untuk Meningkatkan Kualitas Pelayanan. INOVTEK-Seri Informatika, 2(1), 68-72.

[7] Astuti, D., Kartono, K., \& Wardono, W. (2018, February). Analisis Kemampuan Literasi Matematika Model Pembelajaran JUCAMA berpendekatan PMRI dengan Google Form sebagai Self Assessment. In PRISMA, Prosiding Seminar Nasional Matematika (Vol. 1, pp. 69-76).

[8] Warsito, A. B., Yusup, M., \& Rasdiana, E. (2015). Pemanfaatan RinfoDocs Sebagai Media Penyusunan Draft Laporan Dalam Proses Bimbingan Tugas Akhir Pada Perguruan Tinggi. Jurnal CCIT, 8. 